\title{
Historein
}

Vol $11(2011)$

Politics and History

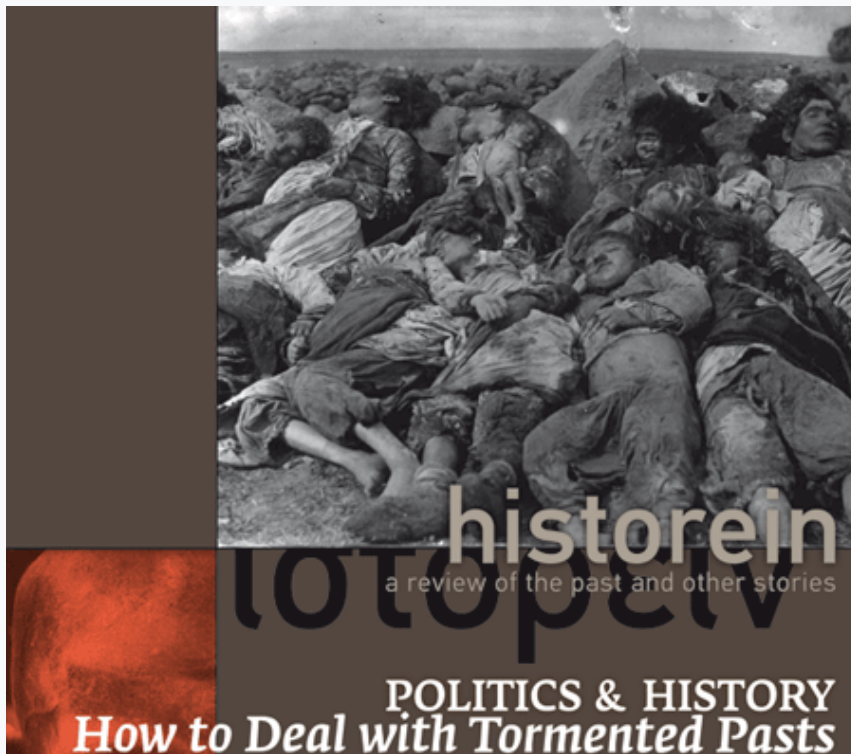

\section{How to Deal with Tormented Pasts}

Antonis Liakos

doi: $10.12681 /$ historein.135

Copyright $\odot 2012$, Antonis Liakos

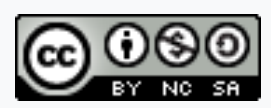

This work is licensed under a Creative Commons Attribution-NonCommercialShareAlike 4.0.

\section{Pierre Nora}

Jörn Rüsen

Wolfgang Benz

Luigi Cajani

Antoon De Baets

\section{To cite this article:}

Liakos, A. (2012). How to Deal with Tormented Pasts. Historein, 11, 5-9. https://doi.org/10.12681/historein.135 


\section{How to Deal with Tormented Pasts}

Since the last quarter of the twentieth century, history has been a battleground regarding the traumatic events of the past, mainly those of the same century. The past has become the apple of discord between historians, governments, lawmakers and the media. Memory wars and memory laws have reproduced each other and this spiral has spread from one country to the other. Although history and politics were always entangled in different forms and roles, today memory laws, history wars, transitional justice and the creation of an international framework of norms regarding the teaching of history at school level are presenting historians with new epistemological problems and moral dilemmas. This volume of Historein addresses the question of how to come to terms with dark pasts: partly in terms of the legacies of division and conflict created by them but mainly those pasts that still create suffering and are related with historical traumas. This is a pressing question because historians are obliged not only to research

\section{Introduction} the past but to shift

their attention from the question of what happened in the past to the question of what is happening in our present regarding its past. This latter question, which is the subject of this issue, marks a shift from history, as an enquiry into the traces of the past, to the historical culture which regards the way in which the past lives in the present and is related to our lives, decisions and future orientations.

The idea to focus this issue originates in the panel on Ethics, Historical Research and Law, organised by Luigi Cajani at the 21st International Congress of Historical Sciences in Amsterdam in August 2010, in which Pierre Nora, Jörn Rüsen, Paolo Pezzino and Antonis Liakos participated. All the speakers agreed that laws attempting to regulate the ways we talk about the past constitute a new field of 
controversy between historians, lawmakers and the European and national parliaments. The initial legislative intervention regarding the denial of the Holocaust was soon followed by new laws condemning north Atlantic slavery, colonial crimes, the communist repression in central and eastern Europe and specific crimes in national historiographies. Pierre Nora, in his intervention "History, Memory and the Law in France, 1990-2010", recognises that governments and legislative bodies have the right to orientate the collective memory but disputes strongly the legal sanctions on topics concerning the representation of the past. He argues that the subjection of historical events to legal qualification renders any further discussion impossible at the risk of sanctions and paralyses research. He explains why he took the initiative to create the French association Liberté pour l'histoire. In his words, "it is up to the politicians to commemorate, to pay homage and to organise compensation; it is up to them to honour the victims. It is up to the historians to do the rest, to establish the facts and to propose interpretations of these facts, restricted by neither constraint nor taboo." Taking an opposite position, Wolfgang Benz, in his article "Holocaust Denial: Anti-Semitism as a Refusal to Accept Reality", argues that the law does not concern itself with historians and truth seekers but only those who deny or tend to marginalise the genocide of six million Jews. The denial or marginalisation of genocide is a typical attitude among people who share a rightwing extremist worldview and who adopt hate speech against Jews and immigrants.

One of the main issues of concern in the public use of history and the memory wars is the conceptualisation of genocides and crimes against humanity. How can these horrific events be conceived? How can we talk and write about the mass killing of human beings and the destruction of their lives? What concepts should be used? Should we adopt a position of historical distance, or should we advocate the cause of the victims? Are genocides just something that happened in the twentieth century, or are historians more able and sensitive to see and explore them now because their mentality and the way of doing history has changed? Antoon De Baets, in his article "Conceptualising Historical Crimes", reflects on the historicity of the concepts we possess and use. "Should crimes committed in the course of history that are comparable to genocide, crimes against humanity or war crimes be referred to as such, whatever the label used at the time?" The framework of the present debate on mass atrocities is the United Nations Convention on the Prevention and Punishment of the Crime of Genocide in 1948. This law introduced a moral dimension in thinking and writing about the past. Does the involvement of morality in historical work strike at the value freedom of historians, one of the pillars of their profession, at least since the rise of nineteenth-century historicism? The neutrality and objectivity demanded of historical scholarship have, in fact, been replaced by open sympathy and a sense of respect for victims, which has gone along with open public revulsion at such acts, captured by the popular expression Never again! Historians could no longer behave as distant and indifferent observers, without taking into consideration the moral ethic and implications of their writings. But does this preoccupation hinder the autonomy of historical thinking and prescribe historical interpretations and representations by the force of law or by political pressure? Jörn Rüsen responds to this question in his article "Using History: The Struggle over Traumatic Experiences of the Past in Historical Culture". For Rüsen, although there is "a clear distinction between political and judicial intentions and norms, on the one hand, and the principles of proper historical thinking ... on the other", there are intersections between politics and law, and historical thinking. Rüsen reads 
these intersections through three successive generations in Germany, where historians shared common perspectives on the past with public opinion. His conclusion is that historical research is not in contradiction with the universal principles of morality. It is the trap of moralistic ethnocentrism which leads historical integrity to be compromised through political intentions.

Since the nineteenth century, historians have had a strong interest in international relations, and the history of foreign policy was a stronghold of their field. But genocides are not only a historical problem. Their politicisation through the question of official recognition, restitution and apologies have implicated history and historians in the forming of international policy. Since the end of the Second World War, petitions requesting recognition of more than 40 genocides from around the world have been submitted to international organisations and national parliaments. Some of them, such as the Armenian genocide, the Ukrainian Holodomor and Japanese atrocities in China and Korea are still the subjects of international dispute. Some others, such as the Rwandan and the Bosnian massacres, are being tried in international criminal courts. A number of genocides or massacres of communities are related to emerging nationalities and their campaign for recognition and emancipation, but there are also genocides espoused mostly by academics and campus activists such as those of the Native Americans and African slaves. Historians were called to advocate or oppose these petitions for official recognition, and, in one way or the other, were deeply implicated in all of these cases. But this involvement, although it allowed historians to address audiences much bigger than their usual readership, was not without consequences for what these audiences expected from them because the legal recognition and the institutionalisation of the Holocaust and the genocides which preceded or followed it affect the expectations of history, change the forms of representation and commemoration of these events and also impose terms on the nature of the related historical debates.

By institutionalising the memory of crimes against humanity, the world order that was established after the Second World War defended a certain way of remembering the past and proclaimed it as a moral value that needs to be respected, even by coercion. In the following years, the expansion of the definition of what constitutes a "genocide" and the drive for recognition led to an effort by various nations or ethnic groups to seek revenge for the injustices they have experienced in the past. The term "genocide", besides being a demand for justice, is a symbol of recognition for crimes committed since it has acquired performative power. It validates in the public memory the suffering of a community and produces a demand that it be respected at home and abroad. When genocides are declared as such, past sufferings acquire the status of a cultural distinction and become a source of moral obligation in politics and international relations.

As a consequence, the official recognition of certain traumas and the institutionalisation of their memory becomes a way of dealing with the past under certain rules. At the same time, the institutionalisation of memory becomes highly selective, and not all memories are considered worthy of safeguarding. Memorialisation of the past in the public domain depends on power relations in the present, and there are horrendous crimes against humanity that are still unrecognised and unpunished because the victims do not have the power to bring their cases before the global public or because the perpetrators are still in power. But respect should be defended, and defended by law. The penalisation of the denial of genocide is the subject of Luigi Cajani's "Crimi- 
nal Laws on History: The Case of the European Union". He refers to the memory laws not only in the countries of the European Union and in the European Parliament but also in Israel, Ukraine and Switzerland. He recognises that memory laws, and in some cases criminal legislation, are now the custodian of memory. Reading his article it is understandable why the intervention of the law in the remembering of the past means that historians and historical institutions can no longer perform their traditional role as the guardians of memory because the relationship with the past is much more diffused and, through the effects of new media, has acquired dimensions that make it impossible for academic institutions to control. The claim to history has become an uncontrollable force, affecting not only the learned elites but also the masses. History is read as literature and the borders between the reception of history, the historical novel and fiction are coming down. In contemporary historical culture, the traumatic stands for the sublime, martyrdom and victimhood stand for the heroic and the past is regarded as a symptomatology of unrelated symptoms and is connected with justice and moral demands. Finally, the new eponymous heroes of the past are not illustrious men but evil people. Marina Cattaruzza, in her article "How Much Does Historical Truth Still Matter?", examines how historical narratives are affected by existing practices of victimisation and self-victimisation. Her purpose is to "examine to what degree the currently widespread attribution of victim status to groups of people in the past can be a hindrance to an unbiased historical analysis. In other words, to what degree do historians tend to adopt in their historical narrative to what I want to call here a "moral narrative".

The changes in the ways we remember, initiated in the postwar period, were the result of synergies which have to do with the experiences of wars and mass sufferings but also with the aspiration to escape from the previous awful period and reconstruct a peaceful future, and in doing so verbalising and dealing with the past as much as possible. Through these shifts, history is now rarely conceived as a social science explaining the course of society. It has been transformed into a discipline focused on our relations with the past, including feelings about the past, the sense of respect, the request for acknowledgement and the attribution of justice. History was called to meet needs such as healing, respect, reconciliation and the moral reconstruction of societies in an environment where representation of the past was passing from the printed to the virtual world. New needs and new environments are outpacing the traditional role of history, as it has been conceived and elaborated in the communities of scholars based on the pursuit of a detached and purposeless knowledge. This shift brought history into the realm of historical culture, where historians are no longer the privileged definers of the relationship of the present with the past. As a consequence, in order to understand the new roles of historical communities, we should move beyond the normative concept of the uses and abuses of history and see history not as a window to the past, asking what happened in the past, but as a window into the house in which we are now living, asking how does the past operate in the present. We should not cease to be interested in the past, but we should also be interested in history as a cultural feature of our present societies; not how history should be conducted, but how it is in fact performing. This inversion of our outlook does not imply indifference to or an acceptance of the irresponsible uses of the past or the manipulation of history and historical consciousness. On the contrary, it helps historians understand better the complexity and the multiple dimensions of the environment in which we now work. Vangelis Kechriotis attempts such an exploration into the historical culture of the Turkey of 2011 in his article "From Oblivion to Obsession: The Uses of 
History in Recent Public Debates in Turkey". He presents two cases, one the TV series on the life of Sultan Süleyman the Magnificent (1494-1566) and the other on a film on Bediüzzaman Said Nursi, a Kurdish scholar and political leader (1868-1960) of the early Republican period. Both events challenged the official version of the past and provoked extended reactions, polemics and debates. For Kechriotis, the political, social and demographic changes in recent Turkey have led to a questioning of the compatibility of individual and group memories with the public versions of the past. The result of this questioning is that state and academic elites have lost "the monopoly over the legitimacy to organise and interpret the past". History becomes an arena where social or ethnic groups demand their emancipation from past stigmas and claim their participation in the shaping of the future. On the same ground, newly emerging elites are establishing their own hegemony and in the process undermining the authority of older ones.

But what about the rigour of historical inquiry? Do historians, at least historians whose work is in the tradition of the European and American scholarly tradition of recent decades, have a distinct role in historical culture and in the uses of the past? What is expected from them in the coming to terms with a the civil war past? Taking the Greek debate on the Second World War and the Greek Civil War as a case study, Thanasis Sfikas and Anna Mahera, in their joint article "Does the lliad need an Agamemnon Version? History, Politics and the Greek 1940s", scrutinise the evidence, the argumentation and the epistemological presupposition of a group of revisionists. Yet, although a juxtaposition between the methodological coherence of historical thinking, on the one hand, and the political use of history, on the other, might be possible in the present, it is very interesting to note that when one views the history of historiography from a long perspective, the differences become more and more indistinct. According to Marja Jalava, in her article "Kulturgeschichte as a Political Tool: The Finnish Case", the methodological modernisation of Finnish historiography and its turn to social history was concomitant with a turn to national history, dissociated from the prevailing model of political history in Sweden.

Viewed from the long perspective and from a cultural point of view, the articles included in this issue of Historein make it obvious how history (or at least public history) has been transformed or understood and conceived as a political culture of back-projected accountability. From this point of view, the historical practices became also part of a broader tendency of verbalising and rationalising differences stemming from wars, civil wars, dictatorships and traumatic experiences. This international or global ideological context has gained increasing importance in shaping national debates and policies and in producing historical narratives in our time.

Antonis Liakos 